\title{
IMPLEMENTASI NILAI-NILAI PANCASILA DALAM MEMBANGUN SIKAP DISIPLIN PADA SISWA SMAN 1 SEKONGKANG
}

\author{
Dwi Cahya Addin', Ahmad Fauzan², Muh. Zubair ${ }^{3}$ \\ 1dwicahya0206@gmail.com*; ${ }^{2}$ ahmadfauzan18@ gmail.com*; 3Zubairfkip@gmail.com*; \\ program studi PPKn, Fakultas Keguruan dan Ilmu Pendidikan
}

Universitas Mataram

\begin{abstract}
ABSTRAK
Penelitian ini bertujuan untuk mengetahui implementasi nilai-nilai Pancasila dalam membangun sikap disiplin pada siswa SMAN 1 Sekongkang. Metode penelitian yang digunakan pada penelitian ini yaitu metode kualitatif dengan pendekatan fenomologi yaitu melihat terhadap fenomena sosial yang terjadi dimasyarakat. Teknik pengumpulan data menggunakan tekhnik Obersvasi, wawancara, dan dokumentasi. Teknik analisis data yang digunakan adalah reduksi data, penyajian data, dan penarikan kesimpulan. Hasil penelitian implementasi nilai-nilai Pancasila dalam membangun sikap disiplin pada siswa SMAN 1 Sekongkang melalui: 1) Implementasi nilai-nilai Pancasila dalam membangun sikap displin pada siswa SMAN 1 Sekongkang pada nilai kemanusiaan dan nilai keadilan dimana siswa membudayakan sikap 5S baik terhadap guru dan teman, tidak saling membedakan antara ras, suku, agama, dan status sosial, serta mematuhi tata tertib disekolah ,2) faktor-faktor yang mempengaruhi dalam membangun sikap disiplin di SMAN 1 Sekongkang yaitu faktor eksternal yaitu dari dari segi lingkungan keluarga (kontrol orang tua), lingkungan sekolah, dan lingkungan masyarakat dan faktor internal yaitu dari segi kondisi jasmani (kelelahan) dan dari segi kondisi psikologis (perhatian, minat, dan motivasi).
\end{abstract}

Kata Kunci: implementasi nilai-nilai Pancasila, sikap disiplin, sila kedua, sila kelima.

\section{IMPLEMENTATION OF PANCASILA VALUES IN BUILDING DISCIPLINE ATTITUDE IN STUDENTS OF SMAN 1 SEKONGKANG}

\begin{abstract}
This study aims to determine the implementation of Pancasila values in building disciplined attitudes in SMAN 1 Sekongkang students. The research method used in this study is a qualitative method with a phenomenological approach, namely looking at social phenomena that occur in the community. Data collection techniques using observation techniques, interviews, and documentation. Data analysis techniques used are data reduction, data presentation, and drawing conclusions. The results of the research on the implementation of Pancasila values in building disciplined attitudes in SMAN 1 Sekongkang students through: 1) Implementation of Pancasila values in building disciplined attitudes in SMAN 1 Sekongkang students on human values and the value of justice where students cultivate $5 S$ attitudes both towards teachers and friends, do not discriminate between race, ethnicity, religion, and social status, as well as comply with school rules. 2) the influencing factors in building discipline at SMAN 1 Sekongkang are external factors, namely in terms of the family environment (parental control), school environment, and community environment and internal factors, namely in terms of physical condition (fatigue) and in terms of psychological conditions (attention, interest, and motivation).
\end{abstract}

Keywords: implementation of Pancasila values, discipline, second precept, fifth precept. 


\section{Jurnal Pendidikan Sosial Keberagaman}

Print-ISSN 2355-4622 Online-ISSN 2622-9021

Vol. 8, No. 2, Desember 2021, halaman 81-89

https://juridiksiam.unram.ac.id/index.php/juridiksiam

\section{PENDAHULUAN}

Pancasila yaitu cara-cara dari nilai-nilai luhur bangsa Indonesia yang secara universal. Nilai-nilai luhur yang terkandung di dalamnya merupakan nilai-nilai luhur yang digali dari budaya bangsa dan memiliki nilai dasar yang diakui secara universal dan tidak akan berubah oleh perjalanan waktu. Nilai-nilai dasar pancasila memiliki serangkaian nilai, yaitu nilai ketuhanan, kemanusiaan, persatuan, kerakyatan, dan keadilan. Menurut Aminullah (2006:621) Kelima nilai tersebut dapat dijadikan landasan pokok, landasan fundamental dalam kehidupan bermasyarakat, berbangsa dan bernegara. Dalam kehidupan bermasyarakat, berbangsa, dan bernegara, manusia disebut juga sebagai makhluk sosial karena manusia tidak dapat hidup sendiri dan selalu membutuhkan bantuan orang lain. Pancasila merupakan sumber dari segala sumber hukum di Negara Indonesia. Karya terbaik yang dimiliki oleh founding father bangsa yang tergali dari jati diri dan nilai-nilai luhur bangsa yang tidak dimiliki oleh bangsa lain. Keterkaitan sila Pancasila memiliki makna dan tujuan yang baik dalam kehidupan, Pancasila dijadikan sebagai refrensi didalam kehidupan sehari-hari untuk dapat mengimplementasikannya didalam bermasyarakat sehingga mampu menjaga kerukunan dan menjaga kesamaan sesama manusia untuk membangun sikap dan tingkah laku dalam lingkup masyarkat sesuai dengan nilai-nilai Pancasila (A. Fauzan dan Edi Kurniawansyah,2020).

Nilai-nilai Pancasila sebagai dasar negara membuat bangsa Indonesia memiliki pondasi dan refrensi dalam berkehidupan untuk dapat dijadikan sebagai tolak ukur dalam kehidupan sehari-hari sehingga seiring perkembangan zaman nilai-nilai Pancasila tetap dijadikan sebagai landasan atau kerangkan dalam berkehidupan. Tujuan pokok Implementasi Pancasila yaitu untuk mengembangkan watak warga negara Indonesia untuk menjadikan bangsa yang tangguh hal ini bertujuan untuk mengahadapi seiring zaman yang berkembang (Reno Wikandru,2019). Pengimplementasian nilai - nilai pancasila dalam kehidupan berbangsa dan bermasyarakat serta dalam kehidupan sehari - hari haruslah bersamaan dengan terbangunnya sikap disiplin seseorang. Istilah disiplin dari bahasa latin "Disciplina" yang mengarah kepada proses belajar mengajar. Istilah tersebut sangat dekat dengan istilah dalam bahasa inggris "Disciple" yang berarti mengikuti orang untuk belajar dibawah pengawasan seorang pemimpin. Dalam kegiatan belajar tersebut, bawahan diajarkan untuk dapat menjaga ketertiban dan menghargai aturan-aturan yang sudah diciptakan pemimpin (Chandra \& Angin,2017).

Dalam kehidupan sehari - hari membangun sikap disiplin dapat ditemukan di lingkungan sekolah. Sejalan dengan perkataan (Sosa,2007), yaitu "mediasi” untuk kontekstualisasi dan implementasi Pancasila adalah melalui sosialisasi dapt dilakukan melalui bidang pendidikan misalkan dalam penerapan dilingkungan sekolah. Disiplin merupakan salah satu sikap dan perilaku yang harus dimilik setiap siswa. Menurut Mirdanda Arsyi (2018) bahwa disiplin sangat diperlukan oleh setiap orang untuk menjadikan pribadinya dengan baik, hal tersebut dikarenakan disiplin menetukan kelancaran seseorang didalam menggapai tujuannya. Didalam sikap disiplin untuk bisa saling menghormati, menghargai, dan saling mencintai antar 


\section{Jurnal Pendidikan Sosial Keberagaman}

Print-ISSN 2355-4622 Online-ISSN 2622-9021

Vol. 8, No. 2, Desember 2021, halaman 81-89

https://juridiksiam.unram.ac.id/index.php/juridiksiam

sesama untuk membentuk sikap dan tingkah laku terhadap lingkungan baik disekolah maupun diluar lingkungan sekolah.

Disiplin adalah ketaatan atau kepatuhan yaitu ketaatan seseorang dalam norma-norma atau kaidah-kaidah hidup lainnya, dengan demikian suatu yang dilakukan tidak bisa dilakukan secara instan, melainkan harus dilakukan dengan cara berulang-ulang untuk menciptakan kemakmuran, dan dibutuhkan sikap disiplin dari siswa untuk menjaga kondisi lingkungan sekolah menjadi lebih baik untuk dapat menjaga atau mematuhi tata tertib yang sudah ditetapkan. Seseorang bisa disebutkan disiplin ketika aturan-aturan atau kaidah-kaidah hukum lainnya sudah dijalankan dengan baik seperti tata tertib sekolah siswa harus mematuhi apa yang menjadi kewajibannya. Salah satu contoh implementasi nilai Pancasila yaitu: Implementasi nilai Kemanusian Yang Adil dan Beradab dalam lingkungan sekolah adalah saling menghormati serta menghargai sesama manusia, saling menjaga perbedaan baik dalam suku, ras, agama, dan status sosial serta berperilaku sdengan adil, jujur, serta membudayakan sikap 5S antar sesama. Sedangkan contoh Implementasi nilai Keadilan Sosial bagi Seluruh Rakyat Indonesia dalam lingkungan sekolah adalah melakukan kegiatan-kegiatan luhur yang bersaskan kekeluargaan dan menciptakan jiwa gotong royong serta memperlakukan sesama manusia tanpa memandang status.

Pada kenyataanya, implementasi nilai - nilai pancasila dalam membangun sikap disiplin di lingkungan sekolah terutama sila kedua "kemanuisaan yang adil dan beradab" yang mana mampu membentuk moral dan etika siswa dalam disiplin menjadi baik dan sila kelima "keadilan bagi seluruh rakyat Indonesia" mampu di implementasikan pada diri siswa SMAN 1 Sekongkang untuk mengembangkan perbuatan yang luhur dan mencerminkan sikap dan suasana kekeluargaan dan gotong-royong tidaklah berjalan seperti seharusnya hal ini berdasarkan hasil studi awal kepada salah satu guru SMAN 1 Sekongkang, Peneliti menemukan beberapa permasalahan. Dimana siswa SMAN 1 Sekongkang kerap melakukan pelanggaran di sekolah dimana siswa sering kali terlambat untuk masuk ke sekolah sebesar $20 \%$, masih ditemukan siswa yang tidak mengerjakan tugas sebesar 10\%, lingkungan sekolah yang masih kotor yang disebabkan karena siswa tidak membuang sampah tidak pada tempatnya sehingga membuat halaman sekolah menjadi kotor $15 \%$, serta berdasarkan data Tahun 2020 sebesar $45 \%$ atau 90 orang siswa yang tidak disiplin dari 201 jumlah keselurahan siswa. melihat akan persoalan seperti ini siswa terkait dengan disiplin siswa terhadap tata tertib disekolah masih kurang. Peneliti juga menemukan beberapa permasalahan lain, dimana siswa SMAN 1 Sekongkang yang terlambat datang sekolah ini dikarenakan ada beberapa siswa yang memiliki jarak rumah dengan sekolah lumayan jauh siswa yang sering terlambat terutama siswa yang berasal dari Desa Tongo, Sejorong dan Maluk, jarak antara Desa Tongo, sejorong dengan sekolah berkisaran $5 \mathrm{Km}$ sedangkan siswa yang dari maluk jarak dengan sekolah SMAN 1 Sekongkang berkisaran $2 \mathrm{Km}$ sehingga ini yang membuat keterlamabatan siswa datang tidak tepat waktu ke sekolah. Demikian pula dengan lingkungan sekolah yang kotor ini disebabkan siswa-siswa SMAN 1 Sekongkang membuang sampah tidak pada tempatnya pada kegiatan jumat bersih terdapat siswa yang tidak ikut serta dalam pelaksanaan tersebut 
dikarenakan kurangnya partisipasi antar sesama. Dengan melihat permasalahan di atas peneliti tertarik melakukan penelitian tentang "Implementasi Nilai-Nilai Pancasila Dalam Membangun Sikap Disiplin Pada Siswa SMAN 1 Sekongkang”.

\section{METODE PENELITIAN}

Metode penelitian yang digunakan dalam penelitian ini yaitu metode kualitatif dengan pendekatan fenomologi. Penelitian ini akan dilaksanakan di SMAN 1 Sekongkang pada kelas X, XI dan XII yang berlokasi di Sekongkang Bawah Kecamatan Sekongkang, Kabupaten Sumbawa Barat (KSB), jalan pendidikan, Provinsi Nusat Tenggara Barat (NTB). Sementara itu waktu pengumpulan data dimulai pada bulan Juni 2021 sampai dengan bulan Juli 2021. Subjek dalam penelitian yaitu guru di SMAN 1 Sekongkang dan Siswa-siswa SMAN 1 Sekongkang khususnya. Teknik pengumpulan data menggunakan tekhnik Obersvasi, wawancara, dan dokumentasi. Teknik analisis data yang digunakan adalah analisis data model miles huberman yaitu reduksi data, penyajian data, dan penarikan kesimpulan. Sedangkan, untuk mengecek keabsahan data menggunakan trianggulasi.

\section{HASIL DAN PEMBAHASAN}

Hasil penelitian ini akan disajikan sesuai dengan urutan masalah yang menjadi fokus penelitian dari hasil pengumpulan data melalui teknik wawancara, observasi, dokumentasi yang telah di gunakan oleh peneliti di SMAN 1 Sekongkang.

\section{A. Implementasi Nilai-Nilai pancasila dalam membangun sikap disiplin pada siswa SMAN 1 Sekongkang. \\ 1. Implementasi Nilai kemanusiaan yang adil dan beradab}

Implementasi nilai kemanusiaan dalam membangun sikap displin siswa, yang mana dalam membangun kesadaran sikap dan perilaku manusia berdasaarkan hasil wawancara dengan informan 1 oleh bapak berinisial HF, informan 2 bapak berinisial MF, informan 3 siswa farid faindra X IPA dan informan 4 siswa Yogi santoso X IPA yaitu, setiap siswa di SMAN 1 Sekongkang sudah menerapkan sila kemanusiaan yang adil dan beradab dalam membangun sikap disiplin, hal itu dapat dilihat dari saling menghargai dan menghormati siswa kepada guru maupun kepada sesama siswa, tidak semena-mena terhadap guru dan teman, menjunjung tinggi nilai kemanusiaan dimana siswa ketika bertemu dengan guru atau sesama teman siswa membiasakan untuk bersalaman dan menyapa serta membudayakan kebiasaan $5 \mathrm{~S}$ (senyum, salam, sapa, sopan, santun).

2. Implementasi nilai keadilan sosial bagi seluruh rakyat Indonesia dalam membangun sikap disiplin siswa di SMAN 1 Sekongkang.

Implementasi nilai keadilan sosial bagi seluruh rakyat Indonesia dalam membangun sikap displin dapat terlihat melalui kerjasama antar siswa didalam lingkungan sekolah tanpa saling membeda-bedakan. Siswa menerapkan nilai-nilai tersebut dengan menyampaikan pendapat baik dalam proses pembelajaran maupun 


\section{Jurnal Pendidikan Sosial Keberagaman}

Print-ISSN 2355-4622 Online-ISSN 2622-9021

Vol. 8, No. 2, Desember 2021, halaman 81-89

https://juridiksiam.unram.ac.id/index.php/juridiksiam

pada kegiatan diluar kelas. Siswa juga bersikap adil dan toleransi antar sesama teman tanpa memandang perbedaan. Berdasarkan hasil wawancara dengan informan 1 bapak $\mathrm{HF}$, informan 2 bapak berinisial MF, informan 3 Dandel XI IPS dan informan 4 Hamdani XI IPS yaitu, erilaku siswa disekolah sudah baik dalam menunujukan sikap disiplin dengan mentaati peraturan sekolah, mengerjakan tugas-tugas sekolah dengan baik, tidak terlambat datang kesekolah dan tidak membuat keributan di dalam kelas maupun diluar kelas untuk menghargai guru dan teman-teman yang sedang belajar.

B) Faktor-Faktor yang mempengaruhi implementasi nilai-nilai Pancasila dalam membangun sikap disiplin di SMAN 1 Sekongkang.

\section{Faktor Eksternal}

\section{a. Lingkungan Keluarga}

Faktor-faktor yang mempengaruhi dalam membangun sikap disiplin yaitu mulai dari faktor eksternal. Berdasarkan wawanacara dengan informan 1 Bapak berinisial HF, informan 2 Bapak berinisial MF, informan 3 Yogi santoso X IPA dan informan 4 Farid faindra siswa X IPAdikatakan bahwa lingkungan keluarga merupakan faktor eksternal yang akan berpengaruh terhadap masa depan anaknya. Motivasi dan arahan yang orang tua berikan dalam lingkungan keluarga seperti saling menolong, saling menghormati antar sesama, disiplin diri, disiplin waktu tentunya akan berpengaruh terhadap anak.

\section{b. Lingkungan sekolah}

Faktor eksternal lain yang mempengaruhi dalam membangun sikap disiplin adalah di lingkungan sekolah. Aspek yang mempengaruhi hal tersebut adalah teman-teman. Berdasarkan hasil wawancara dengan informan 1 Bapak berinisial HF, informan 2 Bapak berinisial MF, informan 3 Tiara nurvita sari siswa kelas X IPS 3 dan informan 4 Dandel kelas X IPS 2. Siswa-siswa membangun sikap disiplin dengan cara saling menghargai dan menghormati baik kepada guru maupun antar sesama. Sebagian besar siswa telah menunjukkan nilai kemanusiaan yang adil dan beradab dalam rangka membangun sikap disiplin dengan tidak membuat keributan atau kegaduhan didalam lingkungan sekolah.

\section{c. Lingkungan Masyarakat}

Berdasarkan hasil wawancara denganinforman 1 Bapak berinisial HF, informan 2 Bapak berinisial MF, informan 3 Nenti febrianti siswa kelas XI IPS 2 dan informan 4 Andina riskiana siswa kelas XI IPS 2 dapat disimpulkan bahwa faktor yang mempengaruhi sikap disiplin di lingkungan masyarakat adalah dampak positif yang diberikan siswa dimana merekadidalam lingkungan masyarakat saling menghargai dan menghormati anatar sesama warga dan berprilaku adil terhadap sesama dan tidak saling membedakan.

\section{Faktor internal}

\section{a. Fisik}




\section{Jurnal Pendidikan Sosial Keberagaman}

Print-ISSN 2355-4622 Online-ISSN 2622-9021

Vol. 8, No. 2, Desember 2021, halaman 81-89

https://juridiksiam.unram.ac.id/index.php/juridiksiam

Salah satu faktor internal yang mempengaruhi dalam membangun sikap disiplin adalah kondisi fisik. Kondisi fisik yang baik akan membantu siswa membangun sikap disiplin dalam kehidupan sehari - hari. Berdasarkan hasil wawancara dengan informan 1 Bapak berinisial HF, informan 2 bapak berinisial MF, informan 3 Yogi santososiswa kelas X IPA dan informan 4 farid faindra siswa kelas X IPA bahwasanya secara umum kondisi fisik siswa SMA 1 Sekongkang baik. Dapat dilihat dari kemampuan siswa mengikuti tata tertib di sekolah dan ikut terlibat dalam kegiatan sekolah seperti jum'at bersih dan upacara bendera pada hari senin.

\section{b. Psikis}

Kondisi psikis juga merupakan faktor internal yang mempengaruhi dalam membangun sikap disiplin. Dengan kondisi psikis yang baik dan stabil siswa dapat menerapkan sikap disiplin dalam kehidupan sehari - hari tanpa dipengaruhi oleh orang lain. Hal ini disimpulkan berdasarkan hasil wawancara dengan informan 1 Bapak berinisial HF, informan $2 \mathrm{MF}$, nforman 3 Tiara nuritasari siswa kelas X IPA dan informan 4 Dandel siswa kelas X IPS 2 yaitu, secara umum kondisi psikis siswa SMA 1 Sekongkang dalam keadaan baik, akan tetapi ada keadaan - keadaan yang membuat mereka merasa kurang adil sehingga menimbulkan kecemburuan sosial terhadap sesama teman ataupun saudara. Adapula kondisi dimana mereka merasa adanya perbandingan sehingga akan membuat perasaan sedih terhadap siswa, inferior, sehingga berpengaruh terhadap sikap disiplin siswa.

\section{PEMBAHASAN}

\section{A. Implementasi nilai-nilai Pancasila dalam membangun sikap disiplin di SMAN 1 Sekongkang}

\section{Implementasi nilai kemanusiaan yang adil dan beradab}

Implementasi nilai kemanusiaan dalam membangun sikap disiplin terlihat pada kegiatan kerja bakti, jumat bersih, dan pada saat guru mengajar tidak membuat kegaduhan dan menyelesaikan tugas sesuai dengan waktu yang sudah ditentukan. Tercermin pula sikap saling menghargai dan menghormati sesama manusia atau sesama siswa tanpa membeda-bedakan dengan membudayakan sikap 5S (senyum, salam, sopan, sanntu, sapa) hal ini menunjukan perilaku menjunjung tinggi nilai kemanusiaan, saling mencintai sesama manusia yang lainnya. Hal ini diperkuat Menurut Wahyuni et al (2016) disiplin dalam lingkungan sekolah memiliki tujuan untuk dapat mengatur sikap dan tingkah laku siswa-siswa didalam lingkungan sekolah.

\section{Implementasi keadilan sosial bagi seluruh rakyat Indonesia}

Implementasi nilai keadilan sosial dalam membangun sikap disiplin siswa terlihat pada saat kegiatan sekolah seperti menegerjakan tugas yang diberikan oleh guru, melakukan kegiatan piket pembersihan kelas secara adil dan kegiatan lainnya. Pada saat itu terlihat jelas bagaimana bentuk kerjasama siswa-siswa, terlihat bahwa 


\section{Jurnal Pendidikan Sosial Keberagaman}

Print-ISSN 2355-4622 Online-ISSN 2622-9021

Vol. 8, No. 2, Desember 2021, halaman 81-89

https://juridiksiam.unram.ac.id/index.php/juridiksiam

siswa-siswa dalam sikap saling tolong - menolong antar sesama manusia tanpa saling membedakan. Sehingga dalam pembagian tugas masing-masing siswa bersikap adil. Perilaku yang ditunjukan siswa ini memberi pengaruh baik terhadap teman-temannya dan khususnya sekolah. Berdasarkan hal tersebut, bahwa di dalam membangun sikap disiplin setiap orang diperlakuan sama dalam berbagai segi kehidupan, baik dalam aspek sosial, aspek politik, hukum dan kebudayaan.

B. Faktor-faktor yang mempengaruhi implementasi nilai-nilai Pancasila

1. Faktor Eksternal

\section{a. Lingkungan keluarga}

Tentunya dalam lingkup keluarga sebagai tempat pertama dan utama siswa orang tua mampu mengajarkan untuk menjadikan anaknya menjadi lebih baik ke depannya, lingkungan keluarga siswa berpengaruh terhadap lingkungan sekolah dikarenakan orang tua mengajarkan motivasi dam menerapkan sikap peduli sosial. Komunikasi keluarga antara siswa dengan orang tua sangatlah penting. Hal ini diperkuat dengan teori Syamsu yusuf (2001:54) lingkungan keluarga merupakan tempat utama anak untuk mendapatkan pendidikan, sebagaimana bahwa orang tua harus mengajarkan kepada anak sejak kecil bagaimana dalam berprilaku baik. Karena orang tua mampu memberikan arahan dan motivasi terhadap anaknya untuk masa depannya.

\section{b. Lingkungan sekolah}

Sekolah memiliki peran penting dalam membangun sikap disiplin siswa, seperti adanya kegiatan sekolah yang melibatkan siswa-siswa sehingga dalam kegiatan ini saling merangkul saat pelaksanaan kegiatan tanpa saling membedakan antara sesama. Sekolah juga sangat penting dalam pembentukan moral siswa, hal ini diperkuat dengan teori Slemeto (2006:23) mengatakan bahwa moral yang ditanamkan dengan baik kepada siswa didalam sekolah akan menghasilkan sikap atau prilaku yang baik bagi para siswa, dengan demikian lingkungan sekolah selalu memberikan arahan dan motivasi dengan baik.

\section{c. Lingkungan masyarakat}

Pengaruh lingkungan tentunya akan berpengaruh terhadap prilaku siswa dikarenakan apa yang mereka lihat di sekeliling lingkungannya akan menjadi contoh bagi siswa. Berdasarkan hasil wawancara bersama beberapa siswa menunjukan bahwa masyarakat mereka pada saat kegiatan gotong royong melihat warga-warga saling meghargai dan saling tolong menolong dalam kegiatan tersebut dan pada saat berkomunikasi dengan orang yang lebih tua menggunakan bahasa yang sopan. Hal tersebut menjadi contoh bagi siswa sehingga mampu di implemntasikan dilingkungan sekolah dalam membangun sikap disiplin. Hal ini diperkuat dengan teori menurut Shocib (1998:23) mengatakan lingkungan masyarakat yang memiliki keberagaman antara yang satu dengan yang lain, 


\section{Jurnal Pendidikan Sosial Keberagaman}

Print-ISSN 2355-4622 Online-ISSN 2622-9021

Vol. 8, No. 2, Desember 2021, halaman 81-89

https://juridiksiam.unram.ac.id/index.php/juridiksiam

ditengah lingkungan masyarakat banyak dijumpai sikap dan tingkah laku masyarakat oleh anak.

\section{Faktor internal}

\section{a. Fisik}

Dengan adanya nilai-nilai Pancasila dalam membangun sikap disiplin siswa dapat mempunyai pedoman untuk membangun moral untuk menjadi lebih baik terkait dengan keadaan fisik siswa-siswa SMAN 1 Sekongkang semuanya baik. Dibuktikan dengan siswa-siswa melakukan kegiatan-kegiatan sekolah, saling membantu dalam kegiatan piket bersih-bersih kelas, melakukan kerjasama dalam kerja bakti, dan memberi pertolongan terhadap teman. Hal ini diperkuat dengan teori menurut Agus Zainul Fitri (2012:20) mengatakan bahwa faktor fisik ikut berperan dalam menentukan disiplin siswa, Karena siswa yang tidak menderita sakit tentunya akan disiplin dibandingkan siswa yang mengalami gangguan fisik tentunya akan menjadi pengaruh dalam membangun sikap disiplin, dalam hal demikian yang dilakukan siswa SMAN 1 Sekongkang sudah baik.

\section{b. Psikis}

Menurut Winkel (1997:32) mengatakan bahwa keadaan psikis akan menjadi penentu untuk masa depan anak, hal ini tentunya akan mempengaruhi minat, bakat, motivasi, konsentrasi. Beberapa faktor yang menjadi kendala terkadang siswa merasa sedih, kurang rasa percaya diri dan membutuhkan perhatian orang tua yang terkadang saling membedakan antara anaknya sehingga berakibat terhadap kurangnya percaya diri siswa, padahal perhatian orang tua sebagai tempat utama siswa untuk selalu mendapatkan motivasi dan arahan. Dengan demikian keadaan psikis siswa - siswa SMAN 1 Sekongkang, dalam melakukan kegiatan extrakurikuler memiliki potensi untuk membangun jati dirinya dan menunjukan minat, bakat, serta konsntrasi dalam mengikuti kegiatan tersebut.

\section{SIMPULAN}

Setelah peneliti menguraikan pembahasan skripsi ini berdasarkan data- data yang diperoleh melalui wawancara langsung dan observasi terhadap beberapa guru dan siswa SMAN 1 Sekongkang maka dapat disimpulkan bahwa:

1. Implementasi nilai-nilai Pancasaila dalam membangun sikap disiplin pada siswa SMAN 1 Sekongkang, sudah cukup bagus. Selain itu juga implementasi penerapan sila kedua Pancasila dan sila kelima Pancasila pada siswa SMAN 1 Sekongkang dengan memberikan pemahaman, memberikan contoh, memperhatikan siswa, ini merupakan cara guru untuk memotivasi siswa dalam membangun sikap disiplin.

2. Faktor yang mempengaruhi dalam membangun sikap disiplin pada faktor internal dari segi kondisi jasmani (kelelahan) dan dari segi kondisi psikologis (perhatian, 


\section{Jurnal Pendidikan Sosial Keberagaman}

Print-ISSN 2355-4622 Online-ISSN 2622-9021

Vol. 8, No. 2, Desember 2021, halaman 81-89

https://juridiksiam.unram.ac.id/index.php/juridiksiam

minat, dan motivasi). Sedangkan pada faktor eksternal adalah dari segi lingkungan

keluarga (kontrol orang tua), lingkungan sekolah, dan lingkungan masyarakat.

\section{DAFTAR PUSTAKA}

A. Fauzan, Edy Kurniawansyah, \& M. S. (2020). Jurnal Civic Education :4(1), 4449.

Chandra, A., \& Angin, A. (2017). Hubungan Perhatian Orang Tua Dan Iklim Sekolah Dengan Disiplin Pada Siswa Smp N 2 Padang Tualang Kabupaten Langkat. Jurnal Phsycomutiara, 1(1), 1-14. http://e-journal.sarimutiara.ac.id/index.php/Psikologi/article/view/129/147

Dewi eka Septiani. (2019). NILAI KARAKTER. In Dewi eka Septiani (Ed.), NILAI KARAKTER (Vol. 87, Issue 1,2).

Juliya, Z. S. (2014). kedesiplinan dalam membangun sikap siswa. Universitas Islan Negeri Maulana Malik Ibrahim, 11-67. http://etheses.uinmalang.ac.id/809/

Lasiyo, Soeprapto, S., \& Wikandaru, R. (2019). Ruang Lingkup Pendidikan Pancasila. Universitas Terbuka, 1-43.

Mas'ud, I., Ali Fahmi, A., \& Abroza, A. (2018). Strategi Pembelajaran Pendidikan Agama Islam Dalam Penananaman Nilai-Nilai Akhlak Siswa Sma Negeri I Sekampung Lampung Timur. FITRAH: Jurnal Kajian IlmuIlmu Keislaman, 4(2), 317. https://doi.org/10.24952/fitrah.v4i2.953

Nurul, mas'ud waqiah. (2013). Pendidikan Karakter. In Persepsi Masyarakat Terhadap Perawatan Ortodontik Yang Dilakukan Oleh Pihak Non Profesional (Vol. 53, Issue 9).

Oktavianna, D. (2019). Penanaman nilai toleransi di pendidikan anak usia dini pelangi kota semarang skripsi.

Rukiyati, dkk, 2013. (2013). Kaelan, Pendidikan Pancasila (Yogyakarta: Paradigma, 2010), 21.7.7-27.

Syamsu Yusuf. (2001:54). Perkembangan Anak Remaja: Bandung. PT. Rineka Cipta.

Slemeto. (2006:23). Faktor Yang Mempengaruhinya. Jakarta: PT. Rineka Cipta.

Setianingsih, D. (2014). Bab I I Kajian Teori Dan Kerangka Pemikiran.9-29.

Shocib. (1998:23). Pola Asuh Orang Tua, Jakarta: Rineka Cipta.

Soares, A. P. (2013). Kedisiplinan. Journal of Chemical Information and Modeling, 53(9), 1689-1699.

Sosa, A. (2007). Implementasi Pancasila. Amblamam, вbl12y (235), 245. http://digilib.unila.ac.id/4949/15/BAB II.pdf

Winkel. (1997). Psikologi Pendidikan dan Evaluasi Belajar. Jakarta: PT. Gramedia Pustaka Utama.

Tisna, K. A. A. P. (2009). ANALISIS NILAI MORAL DAN ETIKA NOVEL "SUKRENI GADIS BALI". 1-27.

Wahyuni, D., Wati, M., \& Ely, R. (2016). Hubungan Kedisiplinan Terhadap Hasil Belajar Siswa Kelas. Pesona Dasar (Jurnal Pendidikan Dasar Dan Humaniora), 3(4), 43-53. https://doi.org/10.24815/pear.v7i2.14753

Widi, E. N. N., Saraswati, P. \& Dayakisni, T. (2017). Kedisiplinan Siswa-Siswi Sma Ditinjau Dari Perilaku Shalat Wajib Lima Waktu. Jurnal Psikologi Islam, 4(2), 135-150. 